\title{
A telemedicina lehetőségei a COVID-19-pandémia kapcsán a nemzetközi és a magyarországi tapasztalatok és ajánlások tükrében
}

\author{
Győrffy Zsuzsa dr. ${ }^{1}$ - Békási Sándor dr. ${ }^{2,3}$ \\ Szathmári-Mészáros Noémi dr. ${ }^{4}$ - Németh Orsolya dr. ${ }^{4}$ \\ 'Semmelweis Egyetem, Általános Orvostudományi Kar, Magatartástudományi Intézet, Budapest \\ ${ }^{2}$ Magyar Máltai Szeretetszolgálat, Egészségügyi Centrum, Budapest \\ ${ }^{3}$ Fitpuli Kft., Telemedicina Munkacsoport, Győr \\ ${ }^{4}$ Semmelweis Egyetem, Fogorvostudományi Kar, Fogászati és Szájsebészeti Oktató Intézet, Budapest
}

\begin{abstract}
A WHO által 2020. március 11 -én hivatalosan is pandémiának nyilvánított COVID-19-járvány ismét felhívja a figyelmet a telemedicina lehetőségeire. Az új koronavírus-fertőzés megfékezése érdekében, az ellátórendszer múködtetése során, a fertőződés kockázatának maximális csökkentése mellett új utakat, módszereket, platformokat kell találnunk. Célunk, hogy szakirodalmi összegzéssel és gyakorlati szempontú útmutatók révén, valamint a hazai telefogászat különleges példáján keresztül bemutassuk, milyen kísérletek történtek a COVID-19-járvány kapcsán a telemedicinának az ellátásba való bevonására mind a nemzetközi, mind pedig a hazai ellátórendszerek különböző szintjein. Mind a nemzetközi, mind a hazai adatok azt mutatják, hogy a telemedicina kiemelt szerepú lehet a triázs folyamatában, a fertőzöttek korai kiemelésében, diagnosztizálásában, ellátásában, betegútjának menedzselésében úgy, hogy a szakszemélyzet nem érintkezik a potenciálisan fertőzött páciensekkel. Ugyancsak fontos szerepe van a gondozott, krónikus betegséggel élő páciensek állapotának távoli monitorozásában, ellátásában és a veszélyeztetett egészségügyi dolgozói csoport ellátásba való visszakapcsolásában. A potenciális előnyök mellett nem szabad megfeledkeznünk a telemedicinális ellátás korlátairól, ugyanakkor fontos kiemelni, hogy széles hozzáférhetősége miatt a veszélyhelyzet kapcsán kellő rugalmasságot adhat mind az alapellátás, mind a szakellátás számára. Éppen ezért mielőbb szükséges a hazai szakmai irányelveket, a jogi és a finanszírozási lehetőségeket e területen hosszú távon fenntartható módon is meghatározni.*
\end{abstract}

Orv Hetil. 2020; 161(24): 983-992.

Kulcsszavak: telemedicina, triázs, COVID-19, orvos-beteg kapcsolat

\section{Possibilities of telemedicine regarding the COVID-19 pandemic in light of the international and Hungarian experiences and recommendations}

The COVID-19 outbreak was formally announced as a pandemic by WHO on the 11 th of March, 2020. This attracts attention to the possibilities of telemedicine again. In support of stopping the spread of the novel coronavirus infection, whilst keeping the healthcare system running and minimizing the risk of being infected, we also need to find new ways, methods, and platforms to deal with this pandemic. By providing a literature overview and sharing practical guidelines, including the special example of Hungarian teledentistry, we present both international and Hungarian initiatives to involve telemedicine on different levels of healthcare systems regarding COVID-19. Both international and national data show that telemedicine can play a major role in the triage process, early identification, diagnosis and treatment of infected individuals, and management of patient pathways in a way that ensures the medical team does not come into contact with potentially infected patients. It also plays an important role in remote monitoring of medical conditions and care of patients with chronic diseases and reconnects vulnerable groups of

*Megjegyzés: A jelen cikk írását 2020. április 30-án zártuk le. A COVID-19-pandémia és az ezzel kapcsolatos kutatások, vizsgálatok dinamikusan változnak azóta is. 
healthcare personnel to the care system. In addition to the potential benefits of telemedicine, we must not forget the limitations of this method. However, it is important to emphasize that due to its wide availability, telemedicine services can provide sufficient flexibility for both primary and specialist care (outpatient and inpatient clinical care). For that very reason, it is an urgent need to define the national professional guidelines, legal and financing possibilities in this field in a long-term sustainable way.

Disclaimer: We closed the writing of this manuscript on the 30th of April, 2020. The COVID-19 pandemic and related research studies still have been changing dynamically since then.

Keywords: telemedicine, triage, COVID-19, doctor-patient relationship

Győrffy Zs, Békási S, Szathmári-Mészáros N, Németh O. [Possibilities of telemedicine regarding the COVID-19 pandemic in light of the international and Hungarian experiences and recommendations]. Orv Hetil. 2020; 161(24): 983-992.

(Beérkezett: 2020. április 30.; elfogadva: 2020. május 4.)

\begin{abstract}
Rövidítések
ÁEEK = Állami Egészségügyi Ellátó Központ; AMA = (American Medical Association) Amerikai Orvosi Szövetség; COVID-19 = (coronavirus disease 2019) koronavírus-betegség 2019; DETECT $=($ Digital Engagement \& Tracking for Early Control \& Treatment) digitális elkötelezettség és követés a korai ellenőrzéshez és kezeléshez; EESZT = Elektronikus Egészségügyi Szolgáltatási Tér; EKG = elektrokardiográfia; $\mathrm{EU}=($ European Union $)$ Európai Unió; GDPR $=($ General Data Protection Regulation) az EU általános adatvédelmi rendelete; NATO $=$ (North Atlantic Treaty Organisation) az Észak-atlanti Szerződés Szervezete; NHS $=($ National Health Service) Országos Egészségügyi Szolgálat (Egyesült Királyság); SARS-CoV-2 = (severe acute respiratory syndrome coronavirus 2) súlyos akut légúti tünetegyüttest okozó koronavírus-2; TTEKG = telemedicina/transztelefonikus EKG; USA = (United States of America) Amerikai Egyesült Államok; WHO $=($ World Health Organization $)$ Egészségügyi Világszervezet
\end{abstract}

A WHO által 2020. március 11 -én hivatalosan is pandémiának nyilvánított COVID-19-járvány világszerte jelentôs kihívások elé állítja a modern egészségügyet. A nagyszámú, egy időben jelentkező fertőződés olyan nyomás alá helyezi a hagyományos ellátórendszert, amelyet csupán személyesen végzett elláással szinte lehetetlen uralni, és ez ismét felhívja a figyelmet a telemedicina lehetőségeire [1].

A jelen pillanatban egy ismeretlen karakterisztikájú betegséggel nézünk szembe, amelynek kezelésében, a fertőződés kockázatának maximális csökkentése mellett, új utakat, módszereket, platformokat kell találnunk [2]. Néhány héttel ezelőtt még a világ kevés országában volt bevett gyakorlat a telemedicina, ma pedig az ellátás szinte elengedhetetlen része. Ennek szellemében többek között az American Medical Association (AMA) [3, 4] és a brit National Health Service (NHS) gyakorlati útmutatókkal segíti orvosait a telemedicina lehetôségeinek maximális kihasználásában $[2,5]$.
A telemedicinának mint távoli orvos-beteg kapcsolaton alapuló ellátási formának szerepe lehet a járvány ideje alatt felmerülő egészségi problémák ellátásában, és kiemelt fontosságot kaphat a fertózöttek korai azonosításában, kiemelésében, diagnosztizálásában, ellátásában, betegútjuk menedzselésében úgy, hogy a szakszemélyzet nem érintkezik a potenciálisan fertőzött páciensekkel, illetve csak a szükséges és ténylegesen sürgősségi beavatkozást igénylő betegek ellátására szorítkozik [1].

A telemedicinának ugyancsak kiemelt szerepe lehet azokban a szociális intézményekben (ápolási otthonok, idősotthonok, hajléktalanellátók), amelyekben jellemzően alapellátási szolgáltatás heti 4-8 órában múködik ugyan, ám a járvány terjedése kapcsán az egészségügyi szolgáltatás iránti igényük megsokszorozódhat. Az ilyen intézmények világszerte könnyen válnak a járvány gócpontjaivá, ezért a koronavírus-fertőzés szempontjából gyanús személyek korai izolációja kulcsfontosságú a zárt közösségeken belüli terjedés megakadályozására. Egy, öt nyugat-európai országra kiterjedő felmérés korai eredménye szerint az ápolási és idősotthonok ellátottjai a mortalitás $42-57 \%$-át adják [6].

\section{Mit is jelent pontosan a telemedicina?}

A „távorvoslás” egyfajta kontinuumként képzelhető el, amely a hagyományos telefonos konzultációtól egészen a távsebészetig történő lehetőségeket takarja [7].

A WHO meghatározása szerint a telemedicina „magában foglalja az információs és kommunikációs technológiák által meghatározott egészségügyi szolgáltatások biztositását, különösen, ahol a távolság akadályozza az egészségïgyi ellátást” $[8,9]$.

Legfontosabb formái:

- Valós időben történő (szinkrón) audio- és videokommunikáció, amely az orvost és a pácienst azonos pillanatban köti össze.

- Különböző egészségügyi adatok (leletek, felvételek) tárolása és továbbítása (jellemzően aszinkrón folya- 
matként, vagyis a két fél közötti információcsere nem igényli mindkettejük azonos időben való jelenlétét).

- Adott paraméter (például vérnyomás, vércukor) távmonitorozása, otthoni dialízis, illetve a különféle viselhető kiegészítők, trackerek, applikációk, szenzorok használata és a mért adatok továbbítása (szintén jellemzően aszinkrón módon, például otthon vezetett digitális napló a krónikus betegségek gondozási folyamatában).

- Tágabb értelemben idetartozhat a telefonos konzultáció vagy az e-mailben történő tanácsadás, de akár egy interneten elérhető, orvosi témájú hanganyag (podcast) vagy a „kérdezz-felelek” jellegü orvosi oldalakon való tanácsadás is.

\section{Felmerülő kérdések a telemedicina kapcsán}

A kutatások azt mutatják, hogy ha a technikai feltételek teljes mértékben adottak, akkor az orvos-beteg kommunikáció hasonlóan zajlik, mint a személyes találkozáskor [10]. A rendelkezésre álló vizsgálatok alapján elmondható, hogy a telemedicinán alapuló orvos-beteg konzultációval mind a páciensek, mind pedig az ellátók elégedettek, és a hagyományos betegellátáshoz képest ezek a kutatások nem számolnak be az ellátásban, illetve a progresszióban történő érdemi különbségekről [11, 12].

A telemedicina pozitívan befolyásolhatja a páciens biztonságérzetét, egészségtudatosságát és adherenciáját $[13,14]$. Más vizsgálatok is kiemelik a telemedicina jelentős idő- és költségcsökkentő hatását [15].

A telemedicina esetében - az egészségügyi rendszer egészéhez hasonlóan - nagyon fontos az elérhetőség, a hozzáférés, a minőség és a költségek kérdése [16]. A telemedicina és általában a digitális technológiák hatékony és széles körü bevezetéséhez számos, hozzáférésen alapuló akadályt kell leküzdenünk. Elsődlegesen fontos feltétel a megfelelő internetlefedettség, sávszélesség és eszközellátottság. Kulcsfontosságú továbbá a társadalmi háttértényezők figyelembevétele (például jövedelem, iskolázottság, egészségértés). Petersen és Bertelsen (2017) vizsgálatukban [17] kimutatták, hogy az alacsonyabb iskolázottságú társadalmi csoportok hozzáférése a telemedicina szolgáltatásához lényegesen alacsonyabb (21\%), mint a magasabb iskolázottságúak esetében $(60 \%)$. A telemedicina alkalmazhatósága nehezített lehet továbbá az idősek körében, különösen akkor, ha ez földrajzi akadályokkal párosul (lásd vidéki kistelepülések) [18]. Ugyanakkor a földrajzi távolság áthidalásában, az elérhetőség növelésében a telemedicina kulcsszerepú lehet [19]. Számos, telemedicinával foglalkozó kutatás számol be a páciensek előzetes felkészítésének, tréningjének fontosságáról [16].

Egyértelmű továbbá, hogy a gyorsan, elhamarkodva bevezetett telemedicina számos veszélyt is rejt magában [20]. Ezek egy része technológiai (a szolgáltatás nyújtása az adatbiztonság szempontjából megbízható platformon történik-e), orvosszakmai (bizonyos betegek, problémák nem láthatók el telemedicina segítségével), míg más részük jogi-etikai természetú (a betegek a telemedicinális ellátásból hogyan adhatók át a definitív terápiát végző orvosnak, hogyan lehet a nemkívánatos eseményeket mérsékelni és a hiányzó betegbiztonsági standardokat pótolni).

A telemedicinát már használó országokban is csak most - a járvány kapcsán - került előtérbe a szabályozás újragondolása és finomhangolása. A járvány mindenhol szükségessé tette a gyors intézkedéseket. Magyarország kormánya is reagált, a veszélyhelyzet kihirdetését követő hónapban tisztázta az online vizit és a távkonzultáció lehetőségét a közfinanszírozott alap- és szakellátásban, ezzel megteremtette a szükséges és elegedhetetlen jogi hátteret a telemedicinális szolgáltatások irányába [21].

A rendelet értelmében telemedicinának minősül Magyarországon az a tevékenység, amelynek célja a beteg távollétében: a beteg egészségi állapotának szakmai megítélése, a betegségek, illetve azok kockázatának felderítése, a konkrét betegség(ek) meghatározása, a beteg állapotának pontosabb megítéléséhez szükséges további vizsgálatok elrendelése, gyógykezelés elindítása, ezen kezelések eredményességének megállapítása (távkonzultáció), valamint a beteg állapotának követése és diagnózis felállítása távmonitoring eszközökkel és egyéb infokommunikációs technológiák révén hozzáférhető információk alapján. A rendelet értelmében a szolgáltatások után az átlagfinanszírozás utólagos elszámolásának keretében a költségek érvényesíthetők.

További fontos feladat a megfelelő minőségbiztosítás tisztázása. Még a telemedicinát több mint 15 éve a saját egészségügyi ellátásukba integráló országoknak (Ausztrália, Egyesült Államok) is folyamatosan javítaniuk kell az erre vonatkozó szabályozásokat. A gyors próbálkozásra friss példa az Amsterdam University Medical Centres kísérlete, amelyben 3 nap alatt állította át járóbeteg-rendelését online konzultációs útra [22]. Az Egyesült Államokban a telemedicina-praxis licenchez, több államban pedig szakvizsgához kötött. A jogi és etikai keretek meghatározása azért is nagyon fontos, mert ez szorosan érinti a betegbiztonság, a betegútmenedzsment kérdését is $[14,23]$.

Egy új rendszer bevezetésekor mindig vannak nehézségek, de nem szabad megfeledkeznünk a hippokratészi esküről és legfő́képpen a „ne árts” alapelvéről. A telemedicina a technológiai háttere miatt is teljesen más készségeket és attitűdöt kíván az egészségügyi dolgozóktól. Fontos ezért, hogy a telemedicinával foglalkozó orvosok megfelelő szakmai tudással és tapasztalattal rendelkezzenek: a képzésre és továbbképzésre nagy hangsúlyt kell fektetni, hogy a betegbiztonság és a minőségi ellátás megmaradhasson.

\section{Hazai telemedicinális előzmények}

A magyarországi egészségügyi gyakorlatban a telemedicina bevezetésére már számos területen történtek kísérletek: létezik telekardiológiai [24], teleradiológiai, tele- 
dermatológiai [25], telepszichiátriai és telepatológiai alkalmazása.

Az Elektronikus Egészségügyi Szolgáltatási Tér (EESZT) elindulása kedvező körülményeket teremtett a „tárolás és továbbítás" típusú technológiai megoldásoknak, a távkonzílium és a távdiagnosztika alkalmazásának. Ezekkel kapcsolatosan az Állami Egészségügyi Ellátó Központ (AEEK) Telemedicina pilotprogramot is szervezett, míg a magánszektor több szereplője is kínál távmonitoring típusú szolgáltatást, például idős vagy krónikusan beteg páciensek gondozása céljából, de akár említhetjük a magzati távfelügyelet rendszerét is. $\mathrm{Ha}$ zánkban az alapellátás szintjén is hozzáférhető és az alkalmazott telemedicina-megoldások terén kiemelhetó például a telekardiológia [26, 27]: az Országos Mentőszolgálat által bevezetett, EKG-alapú távdiagnosztikai rendszer segíti a páciens gyors diagnózisát és a megfelelő ellátóhelyre való irányítását. Múködésének eszköze a minden mentőautóban megtalálható, „Szívőr”-nek nevezett TTEKG-készülék, amely a páciensnek a mentőegység által készített EKG-ját egy szívcentrumba továbbítja, ahol a 0-24 órában szolgálatot teljesítő kardiológus szakorvos („szívfelügyelo””) azonnal értékeli az EKG-t, és ennek alapján a megfelelő fekvőbeteg-ellátóhoz kerül a beteg (infarktus esetén szívcentrumba, egyéb esetben a területileg illetékes megfelelő kórházba irányítják).

\section{Telemedicina a COVID-19 árnyékában}

Általánosságban elmondható, hogy a telemedicina, bár egyre jelentősebb mértékben vesz részt a „hétköznapi” gyógyítómunkában, a koronavírus-járvány előtt arányaiban még azokban az országokban sem volt jelentős, ahol nagyon komoly lépések történtek az egészségügy digitális pályára állításáért, illetve ahol a nagy földrajzi távolságok abszolút indokolták a telemedicina bevezetését $[28,29]$.

Ugyanakkor a telemedicina használata járványok, extrém helyzetek esetében nem újszerü [30]: a 2003-as SARS-járvány után Kína fejlesztette ilyen irányú kapacitásait, Ausztrália a bozóttüzek utáni mentális segítségnyújtásra dolgozott ki telemedicinával kapcsolatos stratégiát [28]. Az American Telemedicine Association Emergency and Response Special Interest Group akciótervet dolgozott ki a katasztrófák esetén használandó lehetőségekről [31, 32], továbbá a NATO Multinational Telemedicine System is kidolgozott extrém helyzetekre vonatkozó forgatókönyveket [33, 34].

A telemedicina segítségével az online vizit időtartama alatt, ha szükséges, további specialistákat vonhatunk be a konzultációba. A jelen járvány idején a Gottsegen György Országos Kardiológiai Intézet például telefonos kardiológiai szakorvosi konzultációt indított [24]. A COVID-19-járvány idején megjelenő új hazai kezdeményezés a Semmelweis Egyetem Bőr-, Nemikórtani és Bőronkológiai Klinikáján elindult teledermatológiai ellátás [25], amelynek célja, hogy a koronavírus-járvány okozta vészhelyzetben a páciensek az orvos-beteg találkozást kerülve, ingyenes online bőrgyógyászati ellátáshoz jussanak az államilag finanszírozott ellátás keretében.

Nem elhanyagolható a járvány által kiváltott pszichés problémák, mentális terhelés kezelésének lehetősége sem a telepszichiátriai ellátáson keresztül $[28,35]$. A nemzetközi tapasztalatok azt mutatják, hogy a SARS-CoV-2-re pozitívan tesztelt orvosok - amennyiben állapotuk jó, vagy tünetmentesek - a karantén ideje alatt is tudnak betegellátó tevékenységet folytatni a telemedicina eszköztárát használva [36]. Ennek azért van jelentősége, mert a SARS-CoV-2-pozitív szakdolgozók és orvosok egy járvány idején szuperterjesztőkké válhatnak, és az adott kórházban vagy rendelőintézetben halmozódások jöhetnek létre. Azok a szakdolgozók és orvosok, akik koruk vagy alapbetegségük miatt a fokozott rizikójú csoportba tartoznak, és emiatt a közvetlen betegellátásban nem tudnak részt venni, a telemedicina segítségével mégis részt vállalhatnak az egészségügyi ellátásban. Ez egyrészt kiterjedhet a primer prevencióra és a népegészségügyi programokra, amelyek során az állampolgárok adott szakterületen személyre szabott tanácsokat és tájékoztatást kapnak az őket érintő kérdésekben. Másrészt a telemedicinális triázs segítségével lehetővé válik a valóban azonnali ellátásra szoruló vagy személyes vizitet igénylő betegek tájékoztatása és kiszűrése.

Az enyhe és középsúlyos COVID-19-esetek monitorozására a telemedicina ugyanúgy lehetőséget ad, mint arra, hogy a gondozott, krónikus betegséggel élő páciensek monitorozását a rendelői megjelenés okozta többletkockázat nélkül, teljesen biztonságos módon ellássuk $[37,38]$, vagy tanácsot adjunk egyszerúbb problémák otthoni megoldásához [39]. A nemzetközi tapasztalatok azt mutatják, hogy a jelen járvány idején például az urológia [40], a bőrgyógyászat [41], a diabetológia [42], a gyermekgyógyászat [43] terén is fontos lépések történtek a telemedicinális lehetőségek mind jobb kihasználásában.

Ugyancsak fontos kérdés az ellátásban dolgozók testilelki egyensúlyának megőrzése - a telemedicina a munkamegterhelés csökkentésével segítséget nyújthat a burnout mérséklésében [44].

\section{Egy speciális terület: a telefogászat bevezetése a Semmelweis Egyetemen}

2020. március 14-én a magyar kormány a fogászati alapellátást, majd március 17-én a szakellátásban dolgozó fogorvosok munkáját a sürgősségi fogászati ellátásra korlátozta. Az aeroszolgeneráló, forgó eszközök használata következtében a fogorvosok kockázata jelentős - a New York Times ábrája [45] jól mutatja, hogy a fertőzöttségnek való kitettség és a fizikai közelség miatt a fogorvosok a sürgősségi ellátókhoz hasonló mértékben a legveszélyeztetettebbek közé tartoznak az egészségügy területén. 
A fenti sürgősségi eljárásrend szükségessé tette a 'teledentistry' hazai bevezetését. Az alábbi három területen tudjuk kihasználni:

1. Pretriázsként, így a betegek csak tényleg indokolt esetben keresik fel az ellátóhelyet, ahol definitív ellátást kapnak.

2. A fogszabályozás alatt állók és a szájnyálkahártyabetegséggel küzdők esetében, akiknek távoli monitorozása lehetséges telefogászati módszerekkel. Ebben az esetben a páciensek képet vagy képeket töltenek fel.

3. A telefogászat alkalmas lehet a lakosság megszólítására, és azoknak a pácienseknek, akiknek az ellátása halasztható, felhívhatjuk a figyelmét az egészségtudatos magatartásra, és primer prevenciós tevékenységet is végezhetünk.

A telefogászat elengedhetetlen része, hogy a betegeknek meg kell tanulniuk, hogyan tudják használni az új rendszert. A programhoz való csatlakozásra oktatóvideó áll rendelkezésre, és a bejelentkezők akár rögtön időpontot is kérhetnek online vizitre. A felület kialakításában a könnyű kezelhetőség kulcsfontosságú szempont.

A páciens megfelelő azonosítását követően nagy jelentősége van, hogy az adott felületre feltöltött adatok, képek visszakereshetók és hosszú távú követésre alkalmasak legyenek. Ehhez megfelelő kapacitású tárhely szükséges.

Korábban a betegek nagy része telefonon és e-mailen keresztül érdeklődött, és sok esetben kénytelen volt személyesen is felkeresni a Fogászati és Szájsebészeti Oktató Intézetet. A telefogászat bevezetésével azonban reméljük, hogy a telefonos megkeresések és az indokolatlan orvos-beteg találkozások száma jelentősen csökkenhet, és ezáltal hatékonyabbá tehető az ellátás, illetve megvalósulhat a prevencióra és a krónikus, folyamatos monitorozásra szoruló nyálkahártyabetegek követése. A telefogászat gyors és hatékony bevezetése nagyon jó hazai példája lehet a telemedicina COVID-19 idején való használatának.

\section{Konkrét telemedicinális megoldások a COVID-19-járvány idején}

\section{A) Tájékoztató megoldások}

A SARS-CoV-2 karakterisztikájával és az általa kialakított COVID-19 jellemzőivel kapcsolatban napról napra bővül a rendelkezésre álló tudományos információ, ezért az újonnan felderített ismereteknek a lakossághoz való minél gyorsabb eljuttatása alapvető a fertőzés megfékezése érdekében. Ugyancsak fontos, hogy a széles körü tájékozódás hiteles forrásból történjen.

Ennek a jelenleg leghatékonyabb formái az online csatornákhoz kötődnek: kormányzati weboldalak, közösségi médiaoldalak, videómegosztókon és népszerü szórakoztató mobilalkalmazásokon (például TikTok - ByteDance, Peking, Kína) keresztüli tájékoztatás. A fentiek hatékony kombinációját alkalmazza például Szingapúr vagy Dél-Korea, amelyek a járvány elleni védekezésben a leghatékonyabb országok közé tartoznak [46].

Magyarországon az Országos Mentőszolgálat ÉletMentő applikációja is bővült egy „Koronavírus-információs gomb"-bal, illetve az applikáció a koronavírus-helyzettel kapcsolatos lényeges és aktuális információkról értesítésekkel is tudja tájékoztatni felhasználóit.

\section{B) Chatbotok, applikációk, automatikus kommunikációra épitó megoldások}

A chatbotok valós online beszélgetést, interakciót szimuláló programok, amelyek a felhasználó által megadott adatokra előre definiált automatizmus szerint reagálnak. Ez alkalmassá teszi őket arra, hogy egészségügyi szakszemélyzet közremúködése nélkül tudják a tüneteket mutató személyeket előszưrni, kategorizálni és a szükséges teendőkról tájékoztatni. Ilyen rendszert vezetett be többek között Szingapúr is [47].

A mobileszközökön futó applikációk alkalmasak arra, hogy a felhasználó telefonjának cellainformációi (vagyis helyadatai) és Bluetooth-kapcsolatai segítségével, az igazolt megbetegedettek adatbázisának összevetésével figyelmeztessenek, ha potenciálisan fertőzött személyekkel találkozhattunk. Ezt használja ki az izraeli Egészségügyi Minisztérium „Shield” nevü alkalmazása is [48].

Egy másik jó példa lehet a 2013-ban létrehozott Babylon Health telemedicina-alkalmazás [49], amely speciális COVID-19-tünet-ellenőrzővel és az enyhe esetek automatikus menedzselésével igyekszik levenni a terhet az egészségügyi dolgozókról.

\section{C) A szenzorok, aktivitásmérök lehetséges felhasználása}

A lakosság egyre szélesebb rétegében érhetők el viselhető kiegészítőkbe épített, kellő megbízhatóságot mutató szenzorok. Ezek népegészségügyi felhasználására korábban számos példa látott napvilágot, és a jelenlegi járványban is látható, hogy az eredetileg fitnesz-wellness célú aktivitásmérók, okosórák adatai akár alkalmasak lehetnek bizonyos tünetek, betegségek populációszintű monitorozására.

Egyrészt az egyedi felhasználás során a korai diagnosztikában segítségünkre lehetnek a beépített szenzorokból (gyorsulásmérő, mozgásérzékelő, pulzusmérő vagy ritkábban pulzoximéter) származó adatok, amelyek megkönnyítik a telemedicinális vizit során az állapotfelvételt, illetve a későbbiekben a betegség progressziójának - akár távoli - nyomon követését.

Másrészt szinte valós időben követhető bizonyos fertőző betegségek területi eloszlása. A Lancet Digital Health 2020. januári száma számolt be egy nagyszabású kutatásról, amely az Egyesült Államok öt államában közel 42 000, Fitbit (Fitbit, Inc., San Francisco, CA, USA) típusú fitnesztrackert használó személy 2016 és 2018 
márciusa között rögzített adataira épült. A vizsgálat eredményei azt mutatják, hogy a pulzusadatok és az alvásmintázat nyomon követésével a jelenlegi járványügyi módszereknél sokkal pontosabban jelezhető az influenzajárvány kitörése, térbeli terjedése [50].

Az amerikai Scripps Research intézet a koronavírusjárvány kitörésekor meghirdette a DETECT elnevezésú tanulmányát, amelyben arra kérte a csatlakozókat, hogy anonim módon osszák meg a különféle szenzoraik, trackereik adatait (szívritmus, pulzus, fizikai aktivitás, alvásmintázat) az egészségi adataik és az esetleges COVID19-cel kapcsolatos tüneteik mellett [51]. A cél az, hogy későbbi járványok során már ezeknek az eszközöknek a jelzései alapján is előre lehessen jelezni a várható megbetegedéseket.

\section{D) Online konzultáció}

Az online konzultáció során a fószerep a tünetek ellenőrzésének, az állapot súlyosság szerinti osztályozásának és a súlyos esetek betegútmenedzsmentjének jut. Az első fázisban az egészségügyi szakszemélyzet felméri a beteg állapotát, tanácsot ad az izolációra és a szükséges teendőkre vonatkozóan (lázcsillapítás, tünetek monitorozása, teszt elvégzése), illetve ha szükséges, a legközelebbi szakellátóhoz, sürgősségi ellátóhelyhez irányítja a beteget [52]. Ezzel a betegek a megfelelő progresszivitási szinten kapják az ellátást, ami időt és a finanszírozónak pénzt takarít meg az egészségügyi rendszer túlterhelése nélkül.

Az online konzultáció vagy vizit mind a szakszemélyzet, mind pedig a beteg oldaláról újszerű képességeket, figyelmet, felkészülést igényel [53]. A Semmelweis Egyetem külön erre a célra készített csekklistát a betegek alapos kikérdezéséhez [54].

Mivel általában az online és különösen a videókapcsolaton alapuló vizitek számos pontjukon eltérnek a megszokott orvos-beteg találkozástól, érdemes a British Medical Journal COVID-19 fókuszú, online vizitre vonatkozó útmutatóját tanulmányozni. Az alábbiakban az ajánlás legfontosabb pontjait emeljük ki a hazai környezetre adaptálva.

Az eredeti cikk teljes szövege magyarul és angolul is olvasható, számos egyéb szakmai anyaggal együtt [2, 55]. A COVID-19-triázs telemedicinára vonatkozó diagnosztikai útmutatója a https://www.bmj.com/content/368/bmj.ml182 linken érhető el.

\section{COVID-19: távoli monitorizálás / kivizsgálás az alapellátásban}

\section{Általános tudnivalók}

- A legtöbb COVID-19-páciens ellátása távolról is lehetséges, a tüneti kezelésre vonatkozó tanácsadással és önkéntes izolációval.
- Ezek a konzultációk többnyire megvalósíthatók telefonon, azonban videókapcsolaton keresztül lehetőség nyílik a jobb vizuális kontrollra és a hatékonyabb terápiás jelenlét megvalósítására.

- Szánjon időt a konzultációval kapcsolatos előkészületekre! Nézze át a páciens kórelőzményét, korábbi diagnózisait, különös tekintettel a COVID-19 szempontjából rizikótényezőt jelentőkre!

- A betegségben a légszomj az egyik legfigyelemfelkeltőbb tünet, jelenleg azonban nincs standardizált mérőeszköz ennek távoli monitorozására. Érdemes nyitott kérdéseket használni, és felmérni, hogy mennyire akadályozza a pácienst a légszomj a beszédben, mélyebb vagy szaporább-e a légzése nyugalomban, illetve a napi rutinját mennyire korlátozza a légzési nehézség.

- A megfelelő biztonsági háló megteremtése kiemelkedően fontos. A beteg számára a betegség várható lefolyásáról releváns tájékoztatást kell adni, illetve arról is be kell számolni, melyek azok a klinikai tünetek, amelyek megjelenése esetén mindenképpen orvosi segítséget kell kérnie. Kérjük meg a beteget, hogy írja fel magának, mit kell tennie akkor, amikor állapota súlyosbodik, vagy fenyegető tünet lép fel! Segítenünk kell abban, hogy pontosan tudja, hol és miként juthat a páciens további orvosi segítséghez.

- Mivel a betegség lefolyása során hirtelen állapotroszszabbodás bármikor felléphet (különösen a betegség második hetében), az egyedül élők számára szükséges egy olyan személyt kijelölni, aki rendszeresen ellenőrzi az állapotukat.

- Küldjön a páciensnek e-mailben hiteles forrásból származó útmutatót, amely segít a COVID-19 otthoni menedzsmentjében, például a házi ápolásra vonatkozóan [56].

\section{Telefon vagy videó?}

- Általában a telefonos konzultáció elegendő enyhe tüneteknél, komplikációmentes esetekben és adminisztratív, tájékozódó jellegü kérdések esetében.

- A videókapcsolat előnye, hogy extra vizuális információk gyüjhetők, így könnyebben juthatunk diagnosztikus jelekhez, és könnyebben biztosítható a megfelelő terápiás jelenlét. Elsősorban súlyosabb eseteknél, krónikus betegséggel küzdőknél, illetve szorongó, nyugtalan pácienseknél javasolt.

- Videókapcsolat esetén, ha a hang- vagy képminőség nem megfelelö, előfordulhat, hogy telefonon kell elérni a pácienst, így érdemes a telefonszámát készenlétben tartani.

- A vizit kezdetén ellenőrizze a páciens személyazonosságát (különösen akkor, ha először beszélnek), és lehetőség szerint közvetlenül magával a beteggel beszéljen, és ne egy képviselőjével! Az online kommunikáció során figyeljen az adatvédelmi szempontokra. 
- Hallászavarral küzdő páciensek számára szerencsésebb lehet a videókapcsolat. Ha a beteg nehezen kommunikál telefonon keresztül, mindenképp a videót válasszuk! Vegyük figyelembe, hogy a betegek egy része önkéntelenül is felnagyíthatja vagy éppen elhallgathatja a tüneteket, így egy videóbeszélgetés alapján a tapasztalt - telemedicinában járatos - orvos ki tudja szû́rni ezeket a félrevezető információkat!

- Bizonyos országok a koronavírus-krízis idejére enyhítik az adatvédelmi szabályokat a videós és egyéb kommunikációs csatornákat illetően, a GDPR-nek szintén van erre vonatkozó záradéka $[2,55]$.

\section{Milyen platformot érdemes használni?}

Célszerü olyan platform mellett letenni a voksot, amelyról az ellátást biztosítónak van korábbi személyes tapasztalata, akár magáncélú felhasználás okán. Így kiélezett helyzetben nagyobb rutinnal tud reagálni, és nem történik időveszteség. Feltehetően a betegek számára is egyszerúbbek és könnyebben használhatók ezek a platformok.

Az AMA ajánlása [57] szerint a járványhelyzetre való tekintettel a hivatalos csatornák mellett a FaceTime (Apple, Inc., Cupertino, CA, USA), a Skype (Microsoft Corporation, Redmond, WA, USA), a Facebook Messenger (Facebook, Inc., Menlo Park, CA, USA) vagy a Google Hangouts (Google LLC, Mountain View, CA, USA) videóplatformja is használható, kerüljük azonban a Facebook Live funkciót vagy a TikTok-ot. Más, telemedicinával foglalkozó szakértők a WhatsApp alkalmazást (WhatsApp, Inc., Mountain View, CA, USA) is megfelelőnek találják [58].
Ha a hang- vagy képminőségen javítani kell, ehhez elöfordulhat, hogy telefonon kell elérni a pácienst, így a telefonszáma legyen készenlétben.

\section{Dokumentációs javaslatok}

A praxisszoftverben vagy más ellátói dokumentációs rendszerben a személyes vizithez hasonló módon szükséges vezetni a dokumentációt. Ebben az aktuális tünettan mellett jelölni javasolt, hogy mely jelekből milyen következtetést vont le az ellátó, milyen diagnózisokat állított fel, illetve milyen további teendőket/betegutat rögzített (beleértve a következő kontroll időpontját, illetve az esetleges kórházi beutalást).

A páciens által, az otthonában mért értékeket is jegyezzük fel, ezek historikus összehasonlítása a hosszú távú követésben és az állapotrosszabbodás azonosításában hangsúlyos szerephez juthat.

A járványügyi intézkedések megkönnyítése érdekében a személyes adatokat (például aktuális tartózkodási hely, elérhetőségek, lehetséges közvetlen kontaktok) minden alkalommal egyeztetni kell, hogy ezek időleges, átmeneti változása ne okozzon fennakadást.

\section{Hogyan készitsük fel a betegeket az online vizitre?}

A betegeket előre fel kell készíteni a telemedicinán keresztüli orvos-beteg találkozás és kommunikáció sajátosságaira [59]. Amennyiben saját szoftvert használunk, annak letöltéséhez és kezeléséhez instrukciókra van Kérem, az online vizit hatékonysága érdekében készítsen listát a jelenlegi (akut) panaszairól (mikor kezdődtek, mennyire súlyosak),
kérdéseit és kéréseit gondolja végig, illetve töltse fel szenzorainak adatait (ha rendelkezésre áll).

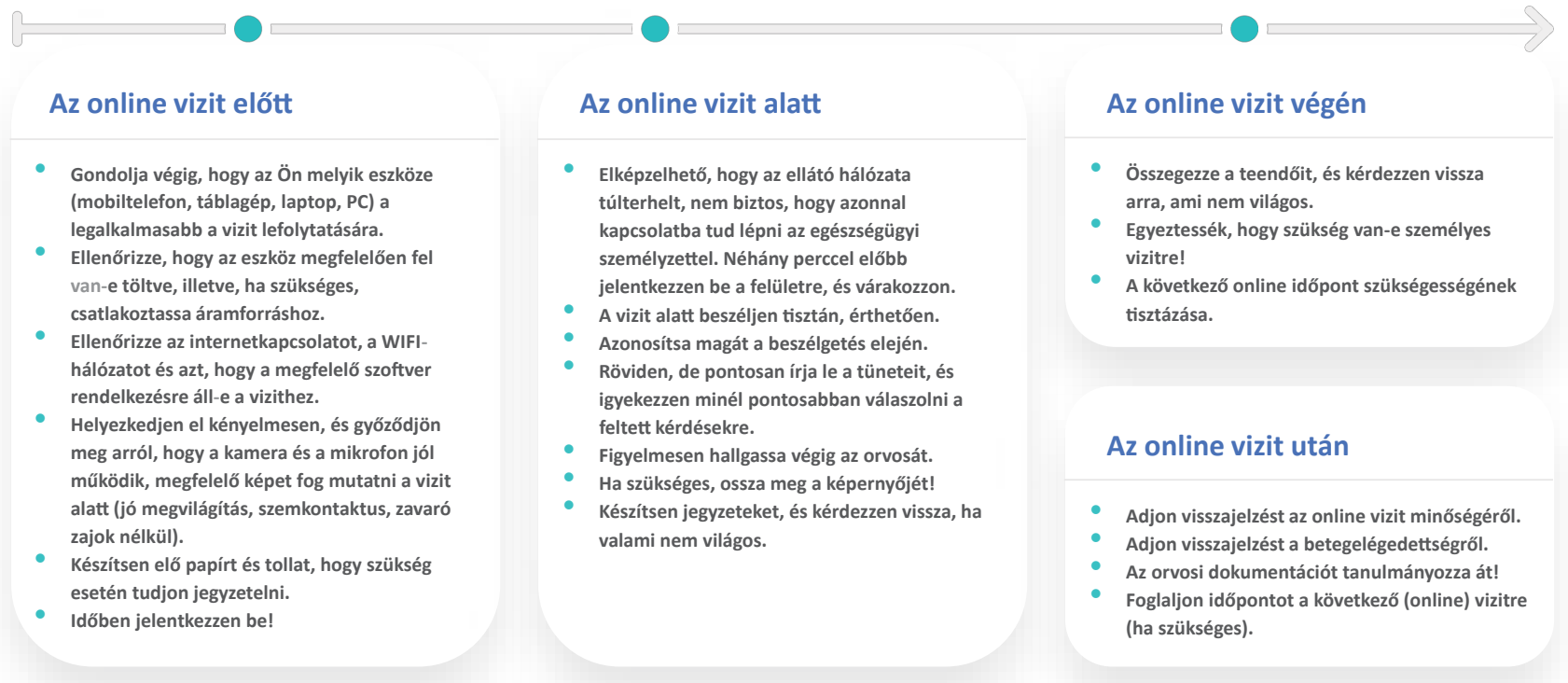

Fontos tudnivaló minden online vizithez: Természetesen a telemedicinán keresztüli orvos-beteg találkozásnak vannak korlátai. Nincs lehetöség fizikális vizsgálat végzésére (például a szív vagy a tüdö részletes vizsgálatára), de alkalmas lehet arra, hogy kezelöorvosa eldöntse, szükséges-e további (esetleg személyes) vizsgálatot kérnie, végeznie. 
szükségük a betegeknek. A felkészüléshez segítségül szolgálhat egy rövid videónak, illetve csekklistának (1. ábra) a betegekkel való megosztása (akár honlapon, e-mailben) még az online vizit előtt.

A telemedicina olyan kultúra terjedését segítheti, amely az új technológiák felhasználására irányítja mind a polgárok, mind az egészségügyi személyzet figyelmét. A személyi jogok védelme, az egészségügyi adatok hozzáférésének szabályozása és manipulálhatóságának megakadályozása, az egészségügyi adattovábbítási, -konvertálási és -tárolási biztonság, azaz a kiberbiztonság előtérbe kerül.

Az Európai Tanács és Parlament által 2011-ben megfogalmazott „határon átnyúló egészségügyi ellátásra vonatkozó betegjogok érvényesítéséről” szóló irányelv (2011/24/EU) alapján Magyarország már részben elkezdte megteremteni a telemedicina jogi alapjait, az igazi áttörést azonban a koronavírus-járvány kapcsán hozott 157/2020. (IV. 29.) Kormányrendelet érheti el, amely, egyelőre időlegesen, de igen előremutatóan rendezi a telemedicina legégetőbb kérdéseit.

Ahhoz, hogy a járványt követően a telemedicina ne csak lehetőség, hanem valóban hatásos eszköz maradjon, elengedhetetlenül szükséges annak hosszú távú, fenntartható módon történő megoldása, valamint az egészségügyi ellátók megfelelő oktatása mind a graduális, mind pedig a posztgraduális képzés során. E tekintetben nagyon fontos kezdeményezés, hogy a „Telemedicina hatása a gyakorlati gyógyító folyamatokra" címú OFTEX-tanfolyam - https://www.oftex.hu/project_o/ actual_prg/system/launch.php?pg=./oftex/TANF_ Adatlap.php? msgid=73754\&tableid $=0$ \&retcode $=$ tanflist - már a hazai posztgraduális képzés részét képezi [60].

Szükséges lenne továbbá egy naprakész adatbázis öszszeállítása, amely összegezné a telemedicina valamely részterületével foglalkozó egészségügyi szolgáltatókat (állami és/vagy magán). Annyi azonban már most is látszik, hogy a telemedicina lehetőségei a COVID-19-járvány után meghatározóak lehetnek az egészségügyi ellátásban.

Anyagi támogatás: A cikk alapjául szolgáló kutatómunka nem részesült anyagi támogatásban.

Szerzői munkamegosztás: A kézirat elkészítésében minden szerző részt vett. A szerzők a cikk végleges változatát elolvasták és jóváhagyták.

Érdekeltségek: A szerzőknek nincsenek érdekeltségeik.

\section{Irodalom}

[1] Grange ES, Neil EJ, Stoffel M, et al. Responding to COVID-19: the UW Medicine Information Technology Services experience. Appl Clin Inform. 2020; 11: 265-275.

[2] Greenhalgh T, Koh GC, Car J. Covid-19: a remote assessment in primary care. BMJ 2020; 368: $\mathrm{ml} 182$.
[3] American Medical Association. Digital health implementation playbook, 2020. Available from: https://www.ama-assn.org/ amaone/ama-digital-health-implementation-playbook [accessed: March 27, 2020].

[4] American Medical Association. Quick guide to telemedicine in practice. Updated April 23, 2020. Available from: https://www. ama-assn.org/practice-management/digital/ama-quick-guidetelemedicine-practice [accessed: March 28, 2020].

[5] Wright JH, Caudill R. Remote treatment delivery in response to the COVID-19 pandemic. Psychother Psychosom. 2020; 89: $130-132$.

[6] Comas-Herrera A, Zalakain J, Litwin C, et al. Mortality associated with COVID-19 outbreaks in care homes: early international evidence. Available from: https://ttccovid.org/2020/ $04 / 12 /$ mortality-associated-with-covid-19-outbreaks-in-carehomes-early-international-evidence/ [accessed: April 12, 2020].

[7] Bán A. Some geographical aspects of telemedicine through the example of Hungary. Doctoral thesis. [A telemedicina néhány földrajzi vonatkozása Magyarország példáján. Doktori értekezés.] Szegedi Tudományegyetem, Természettudományi és Informatikai Kar, Földtudományok Doktori Iskola, Gazdaság- és Társadalomföldrajz Tanszék, Szeged, 2017. [Hungarian]

[8] WHO Global Observatory for eHealth. Telemedicine: opportunities and developments in Member States: report on the second global survey on eHealth. World Health Organization, Geneva, 2010; Vol. 2, 96 p. Available from: https://apps.who.int/iris/ handle/10665/44497 [accessed: April 28, 2020]

[9] WHO Global Observatory for eHealth. Atlas eHealth country profiles: based on the findings of the second global survey on eHealth. World Health Organization, Geneva, 2011; Vol. 1, 230 p. Available from: https://apps.who.int/iris/handle/10665/ 44502 [accessed: April 28, 2020].

[10] Seuren LM, Wherton J, Greenhalgh T, et al. Physical examinations via video for patients with heart failure: qualitative study using conversation analysis. J Med Internet Res. 2020; 22: el6694.

[11] Vimalananda VG, Gupte G, Seraj SM, et al. Electronic consultations (e-consults) to improve access to specialty care: a systematic review and narrative synthesis. J Telemed Telecare 2015; 21 : 323-330.

[12] Caffery LJ, Farjian M, Smith AC. Telehealth interventions for reducing waiting lists and waiting times for specialist outpatient services: a scoping review. J Telemed Telecare 2016; 22: 504512.

[13] Vlahu-Gjorgievska E, Nagapuri S, Win KT. Tele-monitoring technology as a tool for monitoring and management of patients with congestive heart failure. Aust J Inf Syst. 2019; 23: 1-14.

[14] Bán A. The potential role of telemedicine in the improvement of the availability and quality of general practitioner attendance. [A telemedicina potenciális szerepe a háziorvosi ellátás hozzáférhetőségének és minőségének javításában.] Magyar Tudományos Akadémia, Közgazdaság- és Regionális Tudományi Kutatóközpont, Budapest, 2017. [Hungarian]

[15] Wade VA, Eliott JA, Hiller JE. Clinician acceptance is the key factor for sustainable telehealth services. Qual Health Res. 2014; 24: 682-694.

[16] Almathami HK, Win KT, Vlahu-Gjorgievska E. Barriers and facilitators that influence telemedicine-based, real-time, online consultation at patients' homes: systematic literature review. J Med Internet Res. 2020; 22: el6407.

[17] Petersen LS, Bertelsen P. Equality challenges in the use of eHealth: selected results from a Danish citizens survey. Stud Health Technol Inform. 2017; 245: 793-797.

[18] Hollis-Sawyer L. Aging in rural places: policies, programs, and professional practice. Int J Aging Hum Dev. 2015; 81: 207-209.

[19] Dorsey ER, Achey MA, Beck CA, et al. National randomized controlled trial of virtual house calls for people with Parkinson's 
disease: interest and barriers. Telemed J E Health 2016; 22 : 590-598.

[20] Gadzinski AJ, Ellimoottil C, Odisho AY, et al. Implementing telemedicine in response to the 2020 COVID-19 pandemic. J Urol. 2020 Apr 3. Doi: 10.1097/JU.0000000000001033. [Epub ahead of print]

[21] The Government of Hungary. National regulation on health service during the COVID-19 pandemic. [157/2020. (IV. 29.) Kormányrendelet. A vészhelyzet során elrendelt egyes egészségügyi intézkedésekről.] Magyar Közlöny 2020; 91: 22842285. [Hungarian]

[22] Barsom EZ, Feenstra TM, Bemelman WA, et al. Coping with COVID-19: scaling up virtual care to standard practice. Nat Med. 2020 Apr 14. Doi: 10.1038/s41591-020-0845-0. [Epub ahead of print]

[23] Daragó L, Jung Zs, Ispán F, et al. Benefits and disadvantages of telemedicine. [A telemedicina előnyei és hátrányai.] Orv Hetil. 2013; 154: 1167-1171. [Hungarian]

[24] The Government of Hungary. It may be possible to consult nonstop with cardiologists. [Magyarország kormánya. Kardiológus szakorvosokkal lehet nonstop telefonon konzultálni.] Available from: https://koronavirus.gov.hu/cikkek/kardiologus-szakorvosokkal-lehet-nonstop-telefonon-konzultalni? fbclid=IwARlJvO mJMinxljlhRV4ZzC8IPaIkrIIY9INzMqfe_qQHpHLnZL9FksSwo2g [accessed: March 31, 2020]. [Hungarian]

[25] Department of Dermatology, Venereology and Dermatooncology, Semmelweis University. Telemedicine in dermatology. [Semmelweis Egyetem, Bőr-, Nemikórtani és Bőronkológiai Klinika. Távbőrgyógyászati szolgáltatás.] Available from: http:// semmelweis.hu/borklinika/altalanossagban/ [accessed: March 31, 2020]. [Hungarian]

[26] Borbás J, Forczek E, Sepp R, et al. Telecardiology: tasks and duties of telemedicine. [Telekardiológia: A telemedicina feladatai és kötelességei.] Orv Hetil. 2017; 158: 1741-1746. [Hungarian]

[27] Bárány T, Muk B, Osztheimer I, et al. Telecardiology follow-up of pacemaker-implanted patients - inland experiences with home monitoring system. [Pacemaker-implantált betegek telekardiológiai utánkövetése - Hazai tapasztalatok a Home Monitoring rendszerrel.] Cardiol Hung. 2011; 41: 231-238. [Hungarian]

[28] Smith AC, Thomas E, Snoswell CL, et al. Telehealth for global emergencies: implications for coronavirus disease 2019 (COVID-19). J Telemed Telecare 2020 Mar 20. Doi: $10.1177 / 1357633 \times 20916567$. [Epub ahead of print]

[29] Hong YR, Lawrence J, Williams D Jr, et al. Population-level interest and telehealth capacity of US hospitals in response to COVID-19: cross-sectional analysis of Google search and national hospital survey data. JMIR Public Health Surveill. 2020; 6: e18961.

[30] Fidler DP, Gostin LO. The WHO pandemic influenza preparedness framework: a milestone in global governance for health. JAMA 2011; 306: 200-201.

[31] Doarn CR, Merrell RC. Telemedicine and e-health in disaster response. Telemed e-health 2014; 20: 605-607.

[32] Young JD, Abdel-Massih R, Herchline T, et al. Infectious Diseases Society of America position statement on telehealth and telemedicine as applied to the practice of infectious diseases. Clin Infect Dis. 2019; 68: 1437-1443.

[33] Lurie N, Carr BG. The role of telehealth in the medical response to disasters. JAMA Intern Med. 2018; 178: 745-746.

[34] Doarn CR, Latifi R, Poropatich RK, et al. Development and validation of telemedicine for disaster response: the North Atlantic Treaty Organization multinational system. Telemed e-health 2018; 24: 657-668

[35] Zhou X, Snoswell CL, Harding LE, et al. The role of telehealth in reducing the mental health burden from COVID-19. Telemed J E Health 2020; 26: 377-379.

[36] McNamara D. COVID-19: telemedicine gets real, real fast across neurology. Medscape 2020 Mar 28. Available from: https:// www.medscape.com/viewarticle/927714 [accessed: March 31, 2020].

[37] Rogers LC, Lavery LA, Joseph WS, et al. All feet on deck - the role of podiatry during the COVID-19 pandemic: preventing hospitalizations in an overburdened healthcare system, reducing amputation and death in people with diabetes. J Am Podiatr Med Assoc. 2020 Mar 25. Doi: 10.7547/20-051. [Epub ahead of print]

[38] Hollander JE, Carr BG. Virtually Perfect? Telemedicine for Covid-19. N Engl J Med. 2020; 382: 1679-1681

[39] Langabeer JR 2nd, Gonzalez M, Alqusairi D, et al. Telehealthenabled emergency medical services program reduces ambulance transport to urban emergency departments. West J Emerg Med. 2016; 17: 713-720.

[40] Luciani LG, Mattevi D, Cai T, et al. Teleurology in the time of Covid-19 pandemic: here to stay? Urology 2020 Apr 13. Doi: 10.1016/j.urology.2020.04.004. [Epub ahead of print]

[41] Villani A, Scalvenzi M, Fabbrocini G. Teledermatology: a useful tool to fight COVID-19. J Dermatolog Treat. 2020 Apr 13. Doi: 10.1080/09546634.2020.1750557. [Epub ahead of print]

[42] Garg SK, Rodbard D, Hirsch IB, et al. Managing new-onset type 1 diabetes during the COVID-19 pandemic: challenges and opportunities. Diabetes Technol Ther. 2020 Apr 17. Doi: 10.1089/ dia.2020.0161. [Epub ahead of print]

[43] Verstraete SG, Sola AM, Ali SA. Telemedicine for pediatric inflammatory bowel disease in the era of COVID-19. J Pediatr Gastro enterol Nutr. 2020 Apr 8. Doi: 10.1097/MPG. 0000000000002747. [Epub ahead of print]

[44] Moazzami B, Razavi-Khorasani N, Dooghaie Moghadam A, et al. COVID-19 and telemedicine: immediate action required for maintaining healthcare providers well-being. J Clin Virol. 2020; 126: 104345

[45] Gamio L. The workers who face the greatest coronavirus risk. March 15, 2020. Available from: https://www.nytimes.com/ interactive/2020/03/15/business/economy/coronavirusworker-risk.html?action=click\&module $=$ Top + Stories\&pgtype $=$ Homepage [accessed: March 31, 2020].

[46] Dong E, Du H, Gardner L. An interactive web-based dashboard to track COVID-19 in real time. Lancet Infect Dis. $2020 \mathrm{Feb}$ 19. Doi: 10.1016/S1473-3099(20)30120-1. [Epub ahead of print]

[47] Priya S. Singapore government launches COVID-19 chatbot. 2020 February 24. Available from: https://www.opengovasia. $\mathrm{com} /$ singapore-government-launches-covid-19-chatbot/ [accessed: March 29, 2020].

[48] Sommer AK. Israel unveils open source app to warn users of coronavirus cases. 2020 March 23. Available from: https:// www.haaretz.com/israel-news/israel-unveils-app-that-usestracking-to-tell-users-if-they-were-near-virus-cases-1.8702055? fbclid=IwAR20X_159hPfAbGjZcMFRBkc1I0SGLzxlhmPS6jgz BEn17AII54ZN2BAPqs [accessed: March 28, 2020].

[49] Babylon Health. Covid-19 Care Assistant. Available from: https://www.babylonhealth.com/coronavirus/covid-19-care-assistant [accessed: March 29, 2020].

[50] Radin MJ, Wineinger NE, Topol EJ. Harnessing wearable device data to improve state-level real-time surveillance of influenza-like illness in the USA: a population-based study. Lancet-Digital Health 2020; 2: 85-93.

[51] Scripps Research invites public to join app-based DETECT study, leveraging wearable data to potentially flag onset of viral illnesses. 2020 March 25. Available from: https://www.scripps. edu/news-and-events/press-room/2020/20200325-detectstudy-viral-illnesses.html [accessed: April 3, 2020].

[52] Reeves J, Hollandsworth HM, Torriani FJ, et al. Rapid response to COVID-19: health informatics support for outbreak management in an academic health system. J Am Med Informat Assoc. 2020 Mar 24. Doi: 10.1093/jamia/ocaa037. [Epub ahead of print] 
[53] Bán A. The impact of telemedicine on the developement of doctor-patient relationship based on interviews conducted among. [A telemedicina hatása az orvos-beteg kapcsolat átalakulására orvosok körében végzett interjúk eredményei alapján.] LAM 2017; 27: 186-192. [Hungarian]

[54] Department of Hospital Hygiene, Semmelweis University. Checklist for the patient's examination. [Semmelweis Egyetem, Kórházhigiénés Osztály. Csekklista. Ellenőrző lista betegvizsgálathoz.] Available from: http://semmelweis.hu/korhazhigiene/files/2020/03/Csekklista_magyar.pdf [accessed: April 2, 2020]. [Hungarian]

[55] Covid-19: a remote assessment in primary care. [COVID-19: Távkonzultáció az alapellátásban. Available from: https://www. covid 1001.hu/covid-19-tavkonzultacio-az-alapellatasban/ [accessed: April 10, 2020]. [Hungarian]

[56] Semmelweis University. Protocol for domestic care of COVID 19-patients. [Semmelweis Egyetem. Útmutató: a koronavírusos betegek otthoni ápolása.] Available from: http://semmelweis. hu/hirek/2020/03/31/utmutato-a-koronavirusos-betegekotthoni-apolasa/ [accessed: April 19, 2020]. [Hungarian]

[57] American Medical Association. CARES Act: AMA COVID-19 pandemic telehealth fact sheet. AMA, Chicago, IL. Available from: https://www.ama-assn.org/delivering-care/publichealth/ cares-act-ama-covid-19-pandemic-telehealth-fact-sheet [accessed: April 15, 2020].

[58] Jakhar D, Kaul S, Kaur I. WhatsApp messenger as a teledermatology tool during coronavirus disease (COVID-19): from bedside to phone-side. Clin Exp Dermatol. 2020 Apr 3. Doi: 10.1111/ ced.14227. [Epub ahead of print]

[59] eVisit Resources. Technical tips for a successful telemedicine visit. 2018 May 25. Available from: https://evisit.com/resources/ technical-tips-for-a-successful-telemedicine-visit/ [accessed: April 13, 2020].

[60] Szócska G, Kozlovszky M, Ürmösy Á, et al. Virtual doctor's office and televisit as the means and base unit of initially financing telecare. [A virtuális orvosi rendeló és a távvizit - mint az orvosi távellátások kezdeti finanszírozhatóságának eszköze és alapegysége.] IME 2020; 19(1): 23-29.

(Győrffy Zsuzsa dr., Budapest, Nagyvárad tér 4., 1089 e-mail: gyorffy.zsuzsanna@med.semmelweis-univ.hu)

\section{"Mora cogitationis diligentia est." (A hosszas megfontolás a körültekintés bizonyítéka.)}

A cikk a Creative Commons Attribution 4.0 International License (https://creativecommons.org/licenses/by/4.0/) feltételei szerint publikált Open Access közlemény, melynek szellemében a cikk bármilyen médiumban szabadon felhasználható, megosztható és újraközölhetö, feltéve, hogy az eredeti szerző és a közlés helye, illetve a CC License linkje és az esetlegesen végrehajtott módositások feltüntetésre kerülnek. (SID_1) 